\title{
A MÁRKANEVEK VILÁGA
}

Márkákat és márkaneveket mindannyian ismerünk, azok a mindennapjaink részei, még a laikusok is tudják, hogy azok befolyásolják a fogyasztói döntést. Közgazdasági pályát választva, tanulmányaink során is találkozunk velük a marketingkurzusok keretében, többnyire röviden, a márka és a márkaérték részeként említik meg öket. Jelen kötet ennél sokkal részletesebben, 350 oldalon keresztül foglalkozik a márkanevekkel: a monográfia szerzője meggyőzően mutat rá arra, hogy a márkanevekkel miért érdemes és kell foglalkozni.

A kötet a 21. század kutatási trendjeibe illeszkedően interdiszciplináris jellegü: a márkaneveket egyszerre elemzi a gazdaság részeként és nyelvészeti szempontból - a hangsúly azonban egyértelmüen a márkanevek nyelvészeti beágyazottságán van.

A bevezetést követően a kötet második fejezete a gazdaság oldaláról közelít a márkák és a márkanevek világához: bemutatja a termék és a márka közötti különbséget, majd a márkák fontosabb jellemzőit veszi górcső alá: a márkák csoportosítási lehetőségeit, illetve a márkaérték szerepét; végül rámutat arra, hogy minden korszaknak megvannak a saját márkanévadási trendjei. Ez a fejezet releváns lehet a marketingkutatók számára is, de célja inkább a márkanevekkel kapcsolatos ismeretek összefoglalása, mint új összefüggések bemutatása.

A harmadik fejezet képezi a könyv egyik fó irányvonalát: rámutat arra, hogy a márkanevek milyen nyelvészeti eszközökkel vizsgálhatóak, illetve, hogy vonatkozásukban milyen hatásmechanizmussal kell számolni a nyelv kontextusában. Ezen fejezet már a marketingszakemberek számára is gyakorlati haszonnal jár, és új ismeretekkel szolgál. A márkamenedzsment szempontjától különösen érdekes három összefüggés: egyrészt, a hangszimbolikával kapcsolatos kutatások rámutatnak arra, hogy a márkanevek hangzása kiemelt fontosságú. Másrészt, fontos a márkanevek fordításának, illetve fordíthatóságának kérdése: mi dönti el, hogy egy márkanevet érdemes-e egy adott idegen nyelvre fordítani; és amennyiben igen, akkor milyen gyakorlati megoldások és fordítástechnikai eljárások állnak ehhez rendelkezésre. Harmadrészt, releváns a Foreign Language Display szerepe, vagyis az, hogy egy márkanév, illetve annak nyelvi környezete miként tudja összekapcsolni a márkát egy adott nyelvvel vagy kultúrával.

A 4. és 5. fejezet együtt képezi a kötet másik nagy irányvonalát: a márkaasszociációkkal és azok elemzési lehetőségeivel ismerteti meg az olvasót. A 4. fejezet a márkaasszociációk kutatásmódszertani előzményeivel foglalkozik, bemutatva, hogy ez a márkamenedzsment számára kiemelt elméleti és gyakorlati jelentőségü 
vizsgálati terület. Ez vezeti be a könyv empirikus kutatást tartalmazó 5. fejezetét, bemutatva, hogy az elvégzendő vizsgálatok David A. Aaker, Kevin Keller Lane és Franz-Rudolf Esch marketingközpontú, valamint Giep Franzen interdiszciplináris megközelítésére épülnek.

A Kognitív márkareprezentáció - empirikus eredmények címet viselö fejezet tartalmazza a kötet empirikus kutatását: a szerző száz márkanévre gyüjtött két adatfelvétel során 2011-2012-ben, illetve 2015-2016-ban márkaasszociációkat. A márkanevek különböző termékkategóriákhoz tartoznak, amelyek közül jelen kötet kettővel, az alkoholtartalmú italokkal, illetve a személygépkocsikkal kapcsolatos asszociációkat elemzi részletesen.

Az eredmények közül kiemelendő, hogy az egyes termékkategóriák, illetve azokon belül is az egyes szegmensek asszociációinak megoszlása specifikus képet mutat: a szubjektív/objektív asszociációk száma, illetve az attitűdre vonatkozó asszociációk száma alapján elkülönülnek egymástól a gépkocsimárkák esetében a prémium és a tömegmárkák. Az asszociációkban visszatükröződik a reklámozás: azon három italmárka - Borsodi, Suzuki, Unicum - esetében jelentek meg nagy számban reklámelemek (kép, szlogen) asszociációként, amelyek ezeket az elemeket több évig, következetesen használták. Szintén a márkamenedzsmentben hasznosítható eredmény, hogy a vizsgált márkák esetében a leggyakoribb asszociáció minden esetben a termékkategória megnevezése volt; ez alól egyedül a Ferrari kivétel, amelynek legerősebb asszociációja a piros. Ez mutatja, mennyire hasznos lehet egy emblematikus szín összekapcsolása egy márkával. Szintén a gyakorlatban hasznosítható a termékre és a márkára vonatkozó asszociációk elemzése: rámutat arra, hogy a márka tudatos építése elengedhetetlen ahhoz, hogy a megfelelö asszociációk kialakuljanak.

A 6. fejezet a 2. fejezettel alkot keretet: bemutatja, hogy a kötetben leírt, nyelvtudományi alapokon nyugvó megközelítések a márkamenedzsment mely területén, milyen formában alkalmazhatóak. Egy márkanév „életútja” alapján mutat rá a szerző, hogy mely nyelvészeti diszciplínák mely szakaszban, hogyan járulhatnak hozzá a márkanév menedzseléséhez.

Miért érdemes forgatnia a kötetet egy nem nyelvész olvasónak? A monográfia nyelvészeti megközelítése a recenzió írójától távolabb áll, de hasznos volt látni azokat a komplex összefüggéseket, amelyek a márkaneveket jellemzik. Közgazdászok, illetve marketing szakemberek a könyvet elolvasva láthatják, mennyire komplex entitások a márkanevek: milyen szempontrendszert lehet, ajánlatos, illetve kell figyelembe venni ahhoz, hogy a márkanevek hatásmechanizmusát kihasználjuk. A monográfia így egyrészt abban segít, hogy ennek a komplex hatásmechanizmusnak a megértését közelebb hozza az olvasóhoz. Másrészt a kötet széles tárházát kínálja a márkanévadási ötleteknek is: a 3.1 fejezet felosztásai például rávilágítanak arra, milyen sok nyelvi eszköz használható fel az egyedi márkanevek alkotásához. 
A könyv általános érdeklődésre is számot tarthat, ha valaki szélesíteni szeretné ismereteit a márkanevekkel kapcsolatban: a monográfia stílusa olvasmányos és közérthető, a megértést pedig nagyban segíti a sok, szinte mindenki által ismert márkanév példája.

A kötettel kapcsolatban gazdasági szakemberként kritikai momentumot kevésbé tudnék megfogalmazni; a meglátásom szerint azonban a könyvben leírtak sokkal inkább elméleti, mint gyakorlati jellegủek. A monográfiát olvasva úgy gondolom, hogy célszerü lenne a leírtakat egy gyakorlatiasabb megközelítésü könyvben összefoglalni, explicit márkanévadási tippeket és esettanulmányokat hozva példaként; azzal a céllal, hogy az itt összegyüjtött elméleti tudás ne csak az „akadémiai olvasóközönség” számára legyen hasznosítható.

(Kovács László: Márka és márkanév. Márkakutatás és nyelvészet-metszéspontok, lehetöségek, kihivások. Budapest: Tinta Kiadó, 2019)

Keller Krisztina

egyetemi docens Budapesti Corvinus Egyetem Marketing Intézet 